\title{
Exploring Student Perceptions on Teacher-Students Interaction and Classrooms Learning Environments in Indonesian Mathematics Classrooms
}

\author{
Ida Karnasih \\ Universitas Negeri Medan, Indonesia \\ <ikarnasih2001@yahoo.com> \\ Wahyudi \\ SEAMEO QITEP in Mathematics, Yogyakarta, Indonesia \\ <wahyudiw@yahoo.com>
}

\begin{abstract}
Research studies in education that focus on classrooms and school-level learning environments have escalated and produced promising findings that lead to enhancement of the teaching and learning process. The present study reports on the research findings on associations between students' perceptions of their teacher interaction, classroom learning environment and students' outcomes. A sample of 946 students from 43 classes in Indonesia schools completed a survey including the Questionnaire on Teacher Interaction (QTI), What is Happening in This Class (WIHIC) and a scale relating to their attitude towards mathematics classes. Statistical analysis shows that the reliability and validity of the WIHIC and the QTI were confirmed. Cronbach alpha coefficients ranged from 0.66 to 0.85 and from 0.62 to 0.92 for the actual and preferred versions of the Indonesian version QTI, respectively. For the Indonesian version of WIHIC, Cronbach alpha coefficients of seven scales ranged from 0.80 to 0.91 for actual version, and from 0.78 to 0.92 preferred versions. The relationships of classroom environment and interpersonal teacher behaviour with students' attitudinal outcome were identified. Finally, suggestions on the use of the two instruments for teacher professional development were offered.
\end{abstract}

Keywords: Learning environment, Students-teacher interaction, Professional Development, Student Attitude

Most teachers have little control over school policy or curriculum or choice of texts or special placement of students, but most have a great deal of autonomy inside the classroom. Tracy Kidder

\section{Introduction}

Students and teachers spend a considerable amount of time in a formal school setting. The teacher's behaviour, when interacting with students, has been found to have a considerable impact on the nature of learning environment that is created (Fraser, 1989). It is believed that a positive teacher-student relationship stoutly contributes to student learning. Educators, parents and students understand that problematic relationships can be detrimental to student outcomes and development. Productive learning environments are characterised by supportive and warm interactions throughout the class: teacher-student and student-student. Similarly, teacher learning thrives when principals facilitate accommodating and safe school 
cultures. Researchers confirmed that teacher-student interaction is a powerful force that can play a major role in influencing cognitive and affective development of students (Getzel \& Thelen, 1960; Wubbles, Breklmans, \& Hermans, 1987). Furthermore Wubbels and Levy (1993) reaffirmed the role and significance of teacher behaviour in classroom environment and in particular how this can influence students' motivation leading to achievement.

Some reviews show that science and mathematics education researchers have led the world in the field of classroom environment since early 1980s, and that this field has contributed much to understanding and improving science and mathematics education (Fraser 1998; Fraser \& Walberg, 1991). For example, classroom environment assessments provide a means of monitoring, evaluating and improving science and mathematics teaching and curriculum. It is highlighted that a key to improving student achievement and attitudes is to create learning environments that emphasise those characteristics that have been found to be linked empirically with student outcomes (Waldrip \& Fisher, 2002).

International studies in the last four decades have firmly established classroom environment research as a thriving field of study (Fraser, 1998). Past recent classroom environment research has focused on cross-national studies of science classroom environments (Fisher, Rickards, Goh, \& Wong, 1997), constructivist classroom environments (Taylor, Fraser, \& Fisher, 1997), science laboratory classroom environments (McRobbie \& Fraser, 1993) and computer-assisted instruction classrooms (Fisher \& Stolarchuk, 1997; Teh \& Fraser, 1995). Most of researchers reveal promising results of the important role of classroom learning environment on students learning in science classroom. While the area of classroom learning environment research has been internationally established, however, we notice that only very few studies have been done in SEAMEO member countries. Therefore, it is timely to initiate such a study on this area of research in the region.

\section{Review of literatures}

Research studies in education that focus on classrooms and school-level learning environments have escalated and produced promising findings that lead to enhancement of the teaching and learning process. A great deal of progress has involved conceptualisation, assessment and use of learning environments (Fraser, 1989). This research area has captured all school levels from primary to university, urban and rural, cross-national studies beyond non-Western countries, actual and preferred forms, and comparisons between teachers' and students' perceptions of their classroom learning environments, and has employed a number 
of salient and robust instruments that have been validated and revalidated (Fraser, 1998). Furthermore, this research area has also attracted researchers to conduct their research in nonWestern countries, for example, Malaysia, Brunei, Korea, Taiwan, Nigeria, Japan and Papua New Guinea. Thus, there has been an acceptance of the learning environment as a significant variable in predicting the success of educational practice. It seems that the evaluation of the learning environment is as important as evaluating other student performances and outcomes. Reviews of learning environment studies have been provided conveniently and comprehensively, for example, in Fraser's (Fraser, 1994, 1998) studies. Those reviews dissect the development of learning environment research from the beginning to the recent trend of learning environment research. The following paragraphs provide review on the development and use of two instruments employed in this study, namely, What is Happening in this Class (WIHIC) questionnaire and the Questionnaire on Teacher Interaction (QTI).

\section{Overview of and Development and Validation of Questionnaire on Teacher Interaction (QTI)}

By adapting Watzlawick, Beavin, and Jackson's (1967) theory on communication processes, Wubbels, Creton, and Holvast (1988) investigated teacher behaviour in classrooms from a systems perspective in The Netherlands. According to the systems perspective on communication, it is assumed that participants' behaviours influence each other mutually. In classroom, the behaviour of the teacher is influenced by the behaviour of the students and in turn influences student behaviour. Circular communication processes build up which not only consist of behaviour, but also determine behavior as well.

Previously, Wubbels, Creton, and Hooymayers (1985) developed a model to map interpersonal teacher behaviour extrapolated from the work of Leary (1957). This model has been used in The Netherlands in the development of an instrument, the Questionnaire on Teacher Interaction (QTI), to gather students' and teachers' perceptions of interpersonal teacher behaviour (Wubbels, Brekelmans, \& Hooymayers, 1991; Wubbels \& Levy, 1993). This model maps interpersonal behaviour with the aid of an influence dimension (Dominance, D - Submission, S) and a proximity dimension (Cooperation, C - Opposition, O). In their application of the model to the classroom situation, Wubbels, Creton, and Hooymayers (1985) further divided each quadrant of the original model into two sectorsgiving eight sectors in all, each describing different aspects of interpersonal behaviour.

The sectors are labelled DC, CD and so on according to their position in the coordinate system, the letters coding the relative influence of the axes. For example, sectors 
DC and CD are both characterised by Dominance and Cooperation, but in DC Dominance predominates over Cooperation, whereas in CD Cooperation is more evident. The closer two sectors are to each other, the more similar are the teacher behaviours they represent. The Dutch researchers labelled these sectors Leadership, Helping/Friendly, Understanding, Student Responsibility/Freedom, Uncertain, Dissatisfied, Admonishing and Strict behaviour. Figure 1 describes the typical teacher interpersonal behaviours associated with each sector.

The original version of the QTI in Dutch language consisted of 77 items and it was designed to measure secondary students' and teachers' perceptions of teacher-student interactions. After extensive analysis, the 77-item Dutch version was reduced to a 64-item version. This version was translated and administered in the USA (Wubbles \& Levy, 1991; Wubbles \& Levy, 1993). Later an Australian version of the QTI containing 48 items was developed (Fisher, Henderson, \& Fraser, 1995). Scale description and a sample item for each of the eight scales of the QTI are shown in Table 1. The questionnaire is available in Appendix A.

Table 1. Description of Scales in the QTI and Representative Items

\begin{tabular}{lll}
\hline \multicolumn{1}{c}{ Scale Name } & \multicolumn{1}{c}{ Scale Description } & \multicolumn{1}{c}{ Example of the item } \\
\hline Leadership & $\begin{array}{l}\text { Extent to which the teacher provides } \\
\text { leadership to class and hold students } \\
\text { attention. }\end{array}$ & This teacher explains things \\
Helping/Friendly & $\begin{array}{l}\text { Extent to which the teacher is friendly } \\
\text { and helpful towards students. }\end{array}$ & $\begin{array}{l}\text { This teacher helps us with } \\
\text { our work. }\end{array}$ \\
Understanding & $\begin{array}{l}\text { Extent to which the teacher shows } \\
\text { understanding/concern/care to students. }\end{array}$ & $\begin{array}{l}\text { If we don't agree with this } \\
\text { teacher, we can talk about it. }\end{array}$ \\
Students & $\begin{array}{l}\text { Extent to which students are given } \\
\text { opportunities to assume responsibilities } \\
\text { Freedom }\end{array}$ & $\begin{array}{l}\text { We can influence this } \\
\text { teacher. }\end{array}$ \\
Uncertain & $\begin{array}{l}\text { Extent to which the teacher exhibits } \\
\text { his/her uncertainty. }\end{array}$ & $\begin{array}{l}\text { It is easy to make a fool out } \\
\text { of this teacher. }\end{array}$ \\
Dissatisfaction & $\begin{array}{l}\text { Extent to which the teacher shows } \\
\text { unhappiness/dissatisfaction with } \\
\text { students. }\end{array}$ & $\begin{array}{l}\text { This teacher thinks that we } \\
\text { do not know anything. }\end{array}$ \\
Extent to which the teacher shows & The teacher is impatient. \\
admonishing & $\begin{array}{l}\text { Extent to which the teacher strict with } \\
\text { and demanding of students. }\end{array}$ & $\begin{array}{l}\text { We are afraid of this } \\
\text { teacher. }\end{array}$ \\
\hline
\end{tabular}




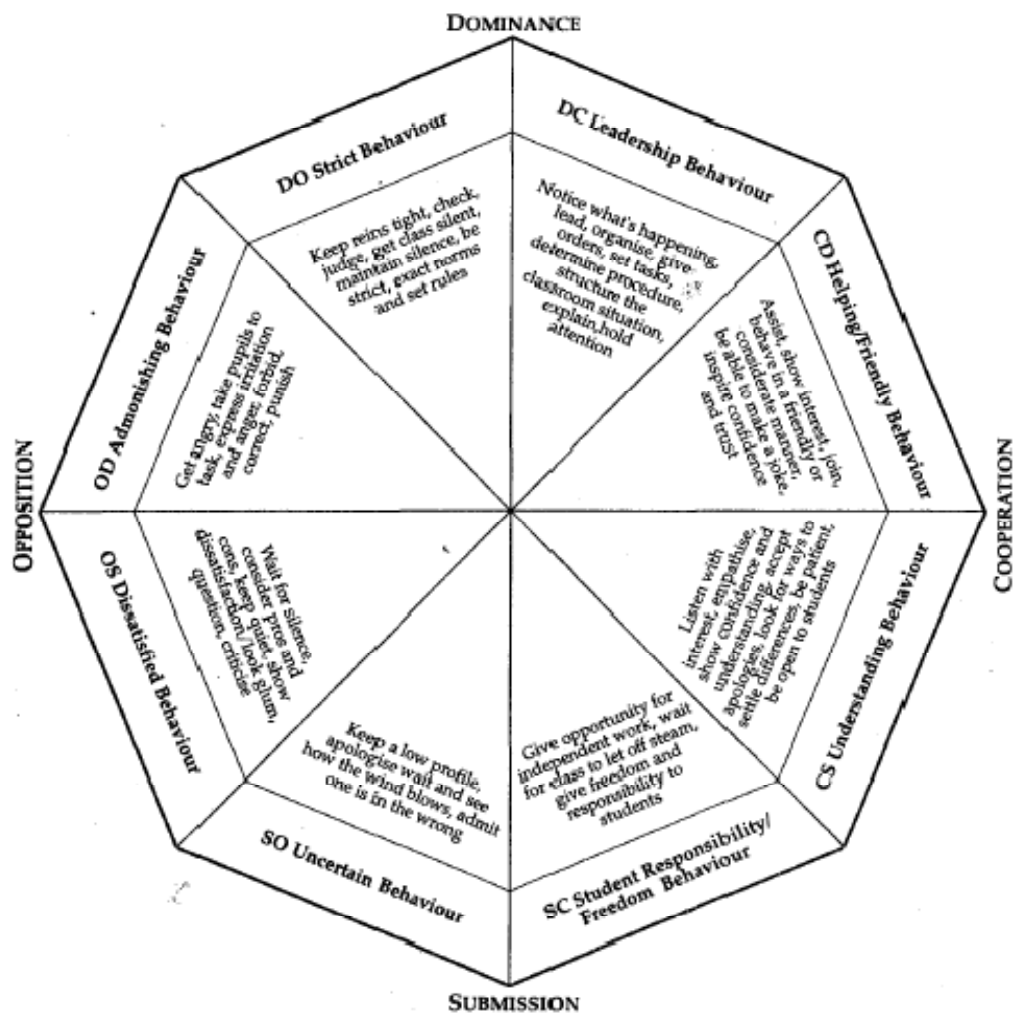

Figure 1. The Wubbels model for teacher interpersonal behaviour (Fisher \& Richard, 1998)

\section{Previous study using the QTI}

The QTI has been shown to be a valid and reliable instrument when used in The Netherlands (Wubbels \& Levy, 1993). When the 64-item USA version of the QTI was used with 1,606 students and 66 teachers in the USA, the cross-cultural validity and usefulness of the QTI were confirmed. Using the Cronbach alpha coefficient, Wubbels and Levy (1993) reported acceptable internal consistency reliabilities for the QTI scales ranging from 0.76 to 0.84 for student responses and from 0.74 to 0.84 for teacher responses.

An initial use of the QTI in The Netherlands involved an investigation of relationships between perceptions on the QTI scales and student learning outcomes (Wubbels, Brekelmans \& Hooymayers, 1991). Regarding students' cognitive outcomes, the more the teachers demonstrated strict, leadership and helping/friendly behaviour, the higher were cognitive 
outcomes scores. Conversely, student responsibility and freedom, uncertain and dissatisfied behaviours were related negatively to achievement. Wubbels and Brekelmans (1998) stated that student outcomes are related to student perceptions of teacher behaviours with affective outcomes displaying a greater association than cognitive outcomes. In fact, studies into student teacher interactions suggest that teachers 'using open teaching styles are able to control student input and procedures in class in order to avoid disorder (Wubbels \& Brekelmans 1998). Wubbels and Levy (1993) claimed that student perceptions of interpersonal teacher behaviour appear to account for 70 percent of the variability in student achievement and 55 percent for attitude outcomes.

Levy, Creton, and Wubbels (1993) analysed data from studies in The Netherlands, the USA and Australia involving students being asked to use the QTI to rate their best and worst teachers. Students rated their best teachers as being strong leaders and as friendly and understanding. The characteristics of the worst teachers were that they were more admonishing and dissatisfied.

The Australian version of the QTI containing 48 items was used in a pilot study involving upper secondary science classes in Western Australia and Tasmania (Fisher, Fraser, \& Wubbels, 1993; Fisher, Fraser, Wubbels, \& Brekelmans, 1993; Fisher, Fraser, \& Henderson, 1995). This pilot study strongly supported the validity and potential usefulness of the QTI within the Australian context, and suggested the desirability of conducting further and more comprehensive research involving the QTI.

Wubbels (1993) used the QTI with a sample of 792 students and 46 teachers in Western Australia and Tasmania. The results of this study were similar to previous Dutch and American research in that, generally, teachers did not reach their ideal and differed from the best teachers as perceived by students. It is noteworthy that the best teachers, according to students, are stronger leaders, more friendly and understanding, and less uncertain, dissatisfied and admonishing than teachers on average. When teachers described their perceptions of their own behaviours, they tended to see it a little more favourably than did their students. On average, the teachers' perceptions were between the students' perceptions of actual behaviour and the teachers' ideal behaviour. An interpretation of this is that teachers think that they behave closer to their ideal than their students think that they do.

Fisher, Rickards, and Fraser (1996) found that after having completed the QTI and having had time to consider the results supplied to them, science teachers reported that they had been stimulated to reflect on their own teaching and verbal communication in the classroom. For example, one teacher concluded that she had become more aware of her 
students' need for clear communication and that this had become a focus for her in improving her classroom teaching (Fisher, Rickards, \& Fraser, 1996).

Fisher and Rickards (1998) analysed a large database of 2,960 student responses to the QTI and found associations between students' perceptions of teacher-student interactions and students' attitudinal and cognitive achievement outcomes. Seven out of eight scales of the QTI were significantly correlated to attitudes to the class and achievement scores when using simple and multiple correlation. It was found that the scales Leadership, Helping/ Friendly, and Understanding were positively and significantly correlated with the attitude to class and the achievement scores. The other QTI scales Uncertain, Dissatisfied, Admonishing and Strict were negatively correlated to the attitude to class and the achievement scores. For cultural differences it was reported that students from Asian background perceived their teachers significantly more positively than did those from the other cultural groups used in the analysis.

Fisher et al. (1997) carried out a similar study involving 720 students in Singapore and 705 students in Australia. In this study the results were the same except that Student Responsibility/ Freedom was also positively associated with students' attitudes towards their science classes in both countries.

The QTI has been used in The Netherlands, USA, Australia, Singapore and a few other Asian countries and has been cross-validated in different contexts and cultures (Fisher \& Rickards, 1998; Fisher et al., 1997; Kim, Fisher, \& Fraser, 2000; Wubbles \& Levy, 1993) All the studies confirm that data obtained from the questionnaire provide valid, reliable and useful information for the teacher regarding their learning environment in general and more specifically about their teacher-student interactions.

Khine and Fisher (2001) administered the QTI to 1,188 students from 54 science classes in Brunei. This study provided further validation data on QTI and indicated that this tool is a valid and reliable instrument to be used in this context. This study showed that students enjoyed the science lessons more when their teachers displayed greater leadership, understanding and are helping and friendly. On the other hand, teachers' uncertain, admonishing and dissatisfied behaviours were negatively associated with the enjoyment of science lessons.

Waldrip and Fisher (2002) employed the QTI to investigate the behavior of good or exemplary teachers. They found that the better or exemplary teachers could be identified as those whose students' perceptions were more than one standard deviation above the mean on 
the scales of Leadership, Helping/Friendly, and Understanding and more than one standard deviation below the mean on the Uncertainty, Dissatisfied and Admonishing scales.

Santiboon (2007) have conducted study in Thailand with a sample of 4,576 students in 245 physics classes at the grade 12 level. The study documented that the associations between students' perceptions of their learning environments and teachers' interpersonal behaviour with their attitudes to their physics classes. This study asserted that in Thailand school context students have a more favourable attitude towards their physics classes if their teachers display good leadership, helping/friendly, understanding, and students responsibility/freedom behaviours and less uncertain, admonishing, dissatisfied and strict behaviours.

\section{Overview of and Development and Validation of the Questionnaire 'What Is Happening In This Class?' (WIHIC)}

The What is Happening In This Class? (WIHIC) questionnaire brings parsimony to the field of learning environment by combining modified versions of the most salient scales from a wide range of existing questionnaires with additional scales that accommodate contemporary educational concerns e.g., equity and cooperation (Fraser, 1998). Based on the previous studies, Fraser, Fisher, and McRobbie (1996) developed this new learning environment instrument. The WIHIC consists of 7 scales and 56 items. The seven scales are Student Cohesiveness, Teacher Support, Involvement, Investigation, Task Orientation, Cooperation and Equity. Table 2 shows the scales in the WIHIC, along with a brief description and a sample item from each scale in the questionnaire. The WIHIC Questionnaire is provided in Appendix B.

Table 2. Descriptions of Scales in WIHIC and Representative Items

\begin{tabular}{lll}
\hline \multicolumn{1}{c}{ Scale Name } & \multicolumn{1}{c}{ Scale Description } & \multicolumn{1}{c}{ Example of the item } \\
\hline $\begin{array}{l}\text { Student } \\
\text { Cohesiveness }\end{array}$ & $\begin{array}{l}\text { Extent to which students know, help, } \\
\text { and are supportive of one another }\end{array}$ & $\begin{array}{l}\text { I help other class members } \\
\text { who are having trouble } \\
\text { with their work. } \\
\text { Teacher Support }\end{array}$ \\
& $\begin{array}{l}\text { Extent to which the teacher helps, } \\
\text { befriend, trust, and shows interest in } \\
\text { students }\end{array}$ & $\begin{array}{l}\text { The teacher considers my } \\
\text { feelings }\end{array}$
\end{tabular}




\begin{tabular}{|c|c|c|}
\hline Scale Name & Scale Description & Example of the item \\
\hline Involvement & $\begin{array}{l}\text { Extent to which students have } \\
\text { attentive interest, participate in } \\
\text { discussion, perform additional work, } \\
\text { and enjoy the class }\end{array}$ & $\begin{array}{l}\text { I give my opinion during } \\
\text { the class discussions }\end{array}$ \\
\hline Investigation & $\begin{array}{l}\text { Emphasis on the skill and processes } \\
\text { of inquiry and their use in problem } \\
\text { solving and investigation }\end{array}$ & $\begin{array}{l}\text { I explain the meaning of } \\
\text { statements, diagrams, and } \\
\text { graphs. }\end{array}$ \\
\hline Task Orientation & $\begin{array}{l}\text { Extent to which it is important to } \\
\text { complete activities planned and to } \\
\text { stay on the subject matter }\end{array}$ & $\begin{array}{l}\text { I am ready to start this class } \\
\text { on time }\end{array}$ \\
\hline Cooperation & $\begin{array}{l}\text { Extent to which students cooperate } \\
\text { rather than compete with one another } \\
\text { on learning tasks }\end{array}$ & $\begin{array}{l}\text { I cooperate with other } \\
\text { students when doing } \\
\text { assignment work }\end{array}$ \\
\hline Equity & $\begin{array}{l}\text { Extent to which students are treated } \\
\text { equally by the teacher }\end{array}$ & $\begin{array}{l}\text { I receive the same } \\
\text { encouragement from the } \\
\text { teacher as other students do }\end{array}$ \\
\hline
\end{tabular}

\section{Previous study using the WIHIC}

The WIHIC questionnaire has been used to measure the psychosocial aspects of the classroom learning environment in various contexts since its development. In certain cases, the questionnaire has been adapted without any modifications, while as in other cases modifications were made to suit the specific context. Currently, the original questionnaire in English has been translated into Chinese for use in Taiwan (Aldridge \& Fraser, 1997) and Singapore (Chionh \& Fraser, 1998), Korean for use in Korea (Kim et al., 2000) and Bahasa Indonesia for use in Indonesia (Wahyudi, 2004).

In a study on associations between learning environments in mathematics classrooms and students' attitudes, Rawnsley (1997) found that students developed more positive attitudes towards their mathematics in classes where the teacher was perceived to be highly supportive, equitable, and where the teacher involved students in investigations.

Hunus and Fraser (1997) used a modified version of the WIHIC in Brunei, and reported on the associations between perceptions of learning environment and attitudinal outcomes. Simple and multiple correlations showed that there was a significant relationship 
between the set of environment scales and students' attitudes towards chemistry theory classes. The Student Cohesiveness, Teacher Support, Involvement, and Task Orientation scales were positively associated with the students' attitudes.

Khoo and Fraser (1998) used a modified version of the WIHIC to measure classroom environment when evaluating adult computer courses. The Cooperation scale was dropped in this modified version and Student Cohesiveness and Teacher Support were collapsed into one scale named Trainer Support. A set of 38 items was retained after factor analyses. This study indicated that the males perceived greater Involvement, while females perceived more Equity. The other striking result of the study was that older females had a more positive perception of Trainer Support than the younger ones.

Fraser and Aldridge (1998) used English and Chinese versions of the WIHIC in Australia and Taiwan, respectively, to explore the potential of cross-cultural studies. Results of the study indicated that students in Australia consistently perceived their classroom environment more positively than students in Taiwan. Significant differences were detected on the WIHIC scales of Involvement, Investigation, Task Orientation, Cooperation and Equity. This indicated that students in Australia perceived they are given more opportunity to get involved in the experiments and investigate scientific phenomena. In this study, cultural differences were highlighted. Education in Taiwan is examination based and teaching styles are adopted to suit the particular situation. In Taiwan, having good content knowledge of the subject was the yardstick for being a good teacher, while as in Australia having good interpersonal relationships between students and teachers is considered the most important factor in education process. Taiwan classrooms are teacher centred giving very little opportunity to students to discuss issues.

Khine and Fisher (2001) used the WIHIC in Brunei to study the classroom environment and teachers' cultural background in an Asian context. The study found that teachers from different cultural backgrounds created different types of learning environments. It also indicated that the WIHIC is a useful instrument with which to measure the cultural background differences and can be used as a basis for identification and development of desirable teacher behaviours that will lead to a favourable learning environment.

Wahyudi (2004) study in Indonesian lower secondary school using the Indonesian version of WIHIC also documented the association between students' perception on their classroom learning environment and their attitudinal and cognitive outcome. Students' enjoyment during science lessons and their attitude toward inquiry in science was greater in 
classrooms that have less cooperation and less student cohesiveness. Students' achievement in school science was negatively influenced by investigation activities during science lessons.

\section{Methodology}

The goals of this study were to provide further cross cultural validation information for the QTI and WIHIC questionnaires when used with a large Indonesian sample; to investigate differences in students' actual and ideal or preferred perceptions of their teacher interpersonal behavior and their classroom learning environment; and to investigate the associations between students' perceptions of teacher interaction and their learning environment with their attitudes toward mathematics.

In more detail, the aims are formulated in the following three research questions:

1. Are the questionnaires used in this study valid and reliable?

2. What are students' perception towards their teacher interpersonal behavior and their classroom learning environment?

3. Are there any associations between teacher interpersonal behavior and classroom learning environment with students' attitude toward mathematics classes?

In so doing, the instruments namely, the Indonesian version of Questionnaire on Teacher Interaction (QTI) and the What is Happening in this Class (WIHIC) questionnaire were developed (See Appendix C and D, respectively). As sugested by Brislin (1970), translataions of the questionnaires into Bahasa Indonesia and then back transalation of both questionnaires into English were carried out. This procedure was done to ensure that the instruments used in the study still carry the original meaning.

The sample was composed of 43 mathematics classes at the lower secondary levels in Indonesia. The total sample involved 946 students spread approximately equally between grades 7, 8, and 9 in 26 different schools. Each student in the sample responded to both actual and preferred versions of the QTI and the WIHIC. Attitude to class was assessed using a seven-item scale based on the Test of Mathematics Related Attitudes (TOMRA) (Fraser, 1981; Fisher, Henderson \& Fraser, 1995), namely Enjoyment toward Mathematics as school subject. 
Exploring Student Perceptions on Teacher-Students Interaction and Classrooms Learning Environments in Indonesian Mathematics Classrooms

\section{Findings and Discussions}

\section{Cross Validation of the questionnaires}

Cronbach's alpha coefficient was calculated using individual scores as the units of analysis. As expected, reliability scores for preferred were higher than actual version for most of scales in both the QTI and WIHIC. Cronbach alpha reliability coefficients for both actual and preferred perceptions of QTI and WIHIC and analysis of variance (ANOVA) eta $^{2}$ results are shown in Tables 3 and 4.

On the whole, the statistics obtained were acceptable. Cronbach alpha coefficients ranged from 0.66 to 0.85 and from 0.62 to 0.92 for the actual and preferred versions of the Indonesian version QTI, respectively. For the Indonesian version of WIHIC, Cronbach alpha coefficients of seven scales ranged from 0.80 to 0.91 for actual version, and from 0.78 to 0.92 preferred versions. These results suggest that the internal consistency for the Indonesian version of QTI and WIHIC are acceptable.

Another desirable characteristic of any instrument like the QTI and WIHIC is that they are capable of differentiating between the perceptions of students in different classrooms. That is, students within the same class should perceive it relatively similarly, while mean within-class perceptions should vary from class to class. This characteristic was explored for each scale of the QTI and WIHIC using one-way ANOVA, with class membership as the main effect. It was found that each QTI and WIHIC scale differentiated significantly $(\mathrm{p}<.01)$ between classes and that the eta ${ }^{2}$ statistic, representing the proportion of variance explained by class membership, ranged from 0.13 to 0.38 for different scales of QTI and from 0.13 to 0.27 for different scales of WIHIC.

Table 3. Internal Consistency Reliability (Cronbach Alpha Coefficient) and ANOVA Results for the Indonesian Version of QTI ( $n=946)$

\begin{tabular}{lccc}
\hline \multicolumn{1}{c}{ Scale Name } & \multicolumn{2}{c}{ Cronbach Alpha Reliability } & $\begin{array}{c}\text { ANOVA results (eta } \\
\text { (Actual) }\end{array}$ \\
\cline { 2 - 3 } & Actual & Preferred & $0.35^{*}$ \\
\hline Leadership & 0.72 & 0.79 & $0.38^{*}$ \\
Helping/Friendly & 0.76 & 0.62 & $0.32^{*}$ \\
Understanding & 0.76 & 0.82 & $0.28^{*}$ \\
Students Responsibility & 0.69 & 0.75 & $0.13^{*}$ \\
Uncertain & 0.78 & 0.87 & $0.22^{*}$ \\
Dissatisfaction & 0.84 & 0.92 & $0.37^{*}$ \\
Admonishing & 0.85 & 0.87 & $0.28^{*}$ \\
Strict & 0.66 & 0.69 & \\
\hline
\end{tabular}

*p<0.01 
Table 4. Internal Consistency Reliability (Cronbach Alpha Coefficient) and ANOVA Results for the Indonesian Version of WIHIC $(n=946)$

\begin{tabular}{lccc}
\hline \multirow{2}{*}{\multicolumn{1}{c}{ Scale Name }} & \multicolumn{2}{c}{ Cronbach Alpha Reliability } & \multirow{2}{*}{ ANOVA results (eta ${ }^{2}$ ) } \\
\cline { 2 - 3 } & Actual & Preferred & \\
\hline Student Cohesiveness & 0.80 & 0.78 & $0.24^{*}$ \\
Teacher Support & 0.84 & 0.79 & $0.27^{*}$ \\
Involvement & 0.84 & 0.87 & $0.17^{*}$ \\
Investigation & 0.89 & 0.90 & $0.13^{*}$ \\
Task Orientation & 0.85 & 0.91 & $0.21^{*}$ \\
Cooperation & 0.83 & 0.82 & $0.14^{*}$ \\
Equity & 0.91 & 0.92 & $0.22^{*}$ \\
\hline
\end{tabular}

${ }^{*} \mathrm{p}<0.01$

Differences between male and female students' perception of the actual mathematics classroom learning environment and interpersonal behaviour of their teacher

Gender differences in teacher-student interpersonal behaviour and in their classroom learning environment were examined using Independent-Sample T-test with the eight QTI scales and seven scales of WIHIC as variables. Table 5 presents the scale means and standard deviations for male and female students' scores on the eight scales of the QTI. Statistically significant gender differences were apparent in students' responses to five of the eight scales of the QTI, with females perceiving greater understanding behaviours in their teachers and males perceiving their teachers as being more uncertain, dissatisfied, admonishing and experience more freedom. The magnitude of these differences is not large but the differences consistently show that females perceive their teachers in a more positive way than do males. 
Table 5. Average Item Mean, Average Standard Deviation (SD), and $t$ Value from t-tests with Independent-Samples T-tests for Differences between Male (n=387) and Female (n=559) Perceptions of QTI

\begin{tabular}{lccccc}
\hline \multirow{2}{*}{ Scale } & \multicolumn{2}{c}{ Average Item Mean } & \multicolumn{2}{c}{ Average SD } & t value \\
\cline { 2 - 4 } & Male & Female & Male & Female & \\
\hline Leadership & 3.82 & 3.88 & 0.57 & 0.54 & -1.74 \\
Helping/Friendly & 3.39 & 3.48 & 0.73 & 0.66 & -1.86 \\
Understanding & 3.81 & 3.98 & 0.67 & 0.56 & $-4.05^{* *}$ \\
Students Responsibility & 2.59 & 2.48 & 0.69 & 0.63 & $2.54^{*}$ \\
Uncertain & 1.66 & 1.54 & 0.68 & 0.55 & $3.08^{*}$ \\
Dissatisfaction & 1.63 & 1.49 & 0.68 & 0.58 & $3.35^{* *}$ \\
Admonishing & 1.81 & 1.71 & 0.77 & 0.69 & $2.05^{*}$ \\
Strict & 2.82 & 2.75 & 0.59 & 0.67 & 1.85 \\
\hline
\end{tabular}

${ }^{* *} p<0.01 ; * p<0.05$

Regarding students' perception of their learning environment as assessed using the Indonesian version of WIHIC, the results of this study maintain the assertions yielded from the previous studies (Goh \& Fraser, 1995; Goh, Young, \& Fraser, 1995; Riah, 1998; Riah \& Fraser, 1998; Wong, 1994), in which females hold better perceptions of the classroomlearning environment than do males. Table 6 suggests that generally females have perceptions slightly more favourable than the males on the actual mathematics classroomlearning environment. While the magnitudes of the differences between male and female students' views of the classroom learning environment are relatively small, statistically significant differences occur on all scales, except on Involvement and Investigation. 
Table 6. Average Item Mean, Average Standard Deviation, and $t$ Value from t-tests with Paired Samples for Differences Between $(n=387)$ and Female $(n=559)$ Perceptions of WIHIC

\begin{tabular}{lccccc}
\hline \multicolumn{1}{c}{ Scale } & \multicolumn{2}{c}{ Average Item Mean } & \multicolumn{2}{c}{$\begin{array}{c}\text { Average Standard } \\
\text { Deviation }\end{array}$} & t value \\
\cline { 2 - 5 } & Male & Female & Male & Female & \\
\hline Student Cohesiveness & 3.98 & 4.08 & 0.53 & 0.48 & $-3.01^{* *}$ \\
Teacher Support & 3.19 & 3.34 & 0.69 & 0.62 & $-3.57^{* *}$ \\
Involvement & 3.07 & 3.14 & 0.64 & 0.59 & -1.67 \\
Investigation & 3.03 & 2.96 & 0.76 & 0.70 & 1.46 \\
Task Orientation & 3.77 & 3.90 & 0.58 & 0.52 & $-3.44^{* *}$ \\
Cooperation & 3.56 & 3.64 & 0.58 & 0.61 & $-2.12^{*}$ \\
Equity & 3.72 & 3.92 & 0.70 & 0.72 & $-4.39^{* *}$ \\
\hline$* * p<0.01 * * p<0.05$ & & & & &
\end{tabular}

Association between Students' Outcomes and Classroom Learning Environments

Correlations between students' perceptions of the mathematics classroom learning environment, their teacher interpersonal behavior and students' outcomes were investigated. Simple and multiple correlations between each scale of the Indonesian WIHIC and QTI and attitudinal outcomes using individual scores as the unit of analysis $(\mathrm{n}=946)$ were conducted. Simple correlations indicated the bivariate association between students' outcomes and each of the scales of the Indonesian WIHIC and QTI. On the other hand, multiple correlations or multiple regression analysis offer the joint and unique influence of each scale in the Indonesian WIHIC and QTI on students' outcomes. A significant beta weight confirms if a scale of the Indonesian WIHIC or QTI is related to students' outcomes when the six scales of WIHIC or seven scale of QTI are mutually controlled. A summary of simple correlation (r), multiple correlations (R) and standardised regression coefficient $(\beta)$ for the association between the QTI and WIHIC and students' outcomes are presented in Tables 9 and 10, respectively.

Simple correlation figures (r) in Table 7 shows all scales of the Indonesian QTI except Students Responsibility are statistically significantly $(p<0.05)$ correlated with students enjoyment in mathematics subjects. The multiple regression analysis produced a significant 
multiple correlation $(\mathrm{R})$ of $0.37(p<0.01)$ for students' enjoyment in mathematics classes. Furthermore, investigations of the value of reveal that Admonishing scale is strong predictor of students' enjoyment during mathematics lessons. Students become less enjoy mathematics lesson when the teachers display more admonishing attitude in the classroom.

Table 7. Simple Correlation (r), Multiple Correlation (R) and Standardised Regression Coefficient ( $\beta$ ) for Association between Teacher Interpersonal Behaviour as measured by the Indonesian version of QTI and Student Attitudes towards Mathematics as School Subjects

\begin{tabular}{|c|c|c|}
\hline \multirow{3}{*}{ QTI Scales } & \multicolumn{2}{|c|}{ Strength of Students Outcomes-Environment Association } \\
\hline & Attitudinal Outcomes (Enjoyn & \\
\hline & $r$ & $\beta$ \\
\hline Leadership & $0.20 * *$ & 0.06 \\
\hline Helping/Friendly & $0.22 * *$ & 0.03 \\
\hline Understanding & $0.28 * *$ & 0.11 \\
\hline Students Responsibility & 0.07 & 0.03 \\
\hline Uncertain & $-0.12 * *$ & -0.08 \\
\hline Dissatisfaction & $-0.19 * *$ & -0.07 \\
\hline Admonishing & $-0.32 * *$ & $-0.28 *$ \\
\hline Strict & $-0.14^{* *}$ & -0.01 \\
\hline Multiple Correlations (R) & & \\
\hline
\end{tabular}


Table 8. Simple Correlation (r), Multiple Correlation (R) and Standardised Regression Coefficient ( $\beta$ ) for Association between Classroom Learning Environments as measured by the Indonesian version of WIHIC and Student Attitudes towards the Subjects

\begin{tabular}{lcc}
\hline \multirow{2}{*}{ WIHIC Scales } & \multicolumn{2}{c}{ Strength of Students Outcomes-Environment Association } \\
\cline { 2 - 3 } & \multicolumn{2}{c}{ Attitudinal Outcomes (Enjoyment) } \\
\cline { 2 - 3 } & \multicolumn{1}{c}{$r$} & $\beta$ \\
\hline Student Cohesiveness & $0.25^{* *}$ & 0.04 \\
Teacher Support & $0.36^{* *}$ & $0.21^{* *}$ \\
Involvement & $0.25^{* *}$ & -0.01 \\
Investigation & $0.17^{* *}$ & -0.09 \\
Task Orientation & $0.39^{* *}$ & $0.40^{* *}$ \\
Cooperation & $0.15^{* *}$ & $-0.15^{*}$ \\
Equity & $0.24^{* *}$ & -0.01 \\
\hline Multiple Correlations $(\mathrm{R})$ & & $0.43^{* *}$ \\
\hline$* \mathrm{p}<0.05 ; * * \mathrm{p}<0.01 ; * * * \mathrm{p}<0.001$ & &
\end{tabular}

Table 8 shows that all scales of the Indonesian WIHIC are statistically significantly $(p<0.05)$ associated with students attitude toward mathematics subjects. The multiple regression analysis produced a significant multiple correlation $(\mathrm{R})$ of $0.43(p<0.01)$ for students' enjoyment mathematics classes. Furthermore, investigations of the value of $\beta$ reveal that the value of Teacher Support $(\beta=0.21, \mathrm{p}<0.01)$, Task Orientation $(\beta=0.40, \mathrm{p}<0.01)$ and Cooperation $(\beta=0 .-15, \mathrm{p}<0.05)$, scales of the Indonesian WIHIC are strong predictors of students' enjoyment in mathematics classrooms. Inspection of the $\beta$ sign indicates some negative relationships exits between some scales of the Indonesian WIHIC and students' enjoyment in mathematics classrooms. Table 8 indicates that students' enjoyment during mathematics are greater in classrooms that have less cooperation but have a good teacher support and clear task direction. 


\section{Conclusions and Recommendations}

This study has explored associations between students' perceptions of their teacher interpersonal behavior, classroom learning environment and their attitude toward mathematics classes.

This study confirmed the reliability and validity of the QTI and WIHIC when used in lower secondary mathematics classes in Indonesian school context. It is found in this study that there are differences on students' perceptions toward their teacher interpersonal behavior and their classroom learning environment based on actual and preferred version as well as based on students' gender. As expected, even though to such extend students are contented with their actual perceptions on both the QTI and WIHIC scales, however, they would like to have more positive experience of teacher interaction and to have more conducive classroom learning environment. This study also found gender differences that consistently showed that females perceive their teachers in a more positive way than do males. Female students also consistently perceive their mathematics classroom environment more favorable than their male counterparts do.

Regarding the association between students' perception of learning environment and their attitude toward science and mathematics, generally the dimensions or scales of the QTI and WIHIC were found to be significantly associated with student attitudes. In particular, the study showed that there was a positive correlation between student attitude toward mathematics classes and the teachers' leadership, helping/friendly and understanding behaviours. Students had a more positive attitude to their mathematics classes when their teacher exhibited more of these behaviours and less admonishing, dissatisfied, uncertain and strict behaviours. If mathematics teachers want to promote favourable student attitudes to their class, they should ensure the presence of these interpersonal behaviours.

This research is of practical significance in that it has drawn a link between student attitudes and the nature of the teacher-student behaviour in the classroom. The study could be of significance for teacher educators and policy makers in that it provides a way of improving student outcomes by changing the nature of classroom learning environment and the existence of interpersonal relationships between students and teachers in mathematics classrooms.

Future research should be planned to help teachers in using these two instruments for improving their teaching performance. A study on better or exemplary teachers as suggested by Waldrip and Fisher (2002) would be advised to be done in Indoensia and SEAMEO 
member countries so that the teachers from this region may share and learn from each other through the best practices found from the research.

It is also advisable for teacher training centre or the university to take into consideration the important of knowledge of teacher interpersonal behaviour and learning environment. To provide student teachers with adequate knowledge, therefore, learning environments can be included as mandatory unit course in the university or teacher training centre. 


\section{References}

Aldridge, J. M., \& Fraser, B. J. (1997, August). Examining science classroom environments in a cross-national study. Paper presented at the 12th WAIER Research Forum for the Western Australian Institute for Educational Research, Perth, Australia.

Brislin, R. W. (1970). Back translation for cross-cultural research. Journal of Cross-Cultural Psychology, 1, 185-216.

Chionh, Y. H., \& Fraser, B. J. (1998). Validation and use of the 'What is Happening in this Class' (WIHIC) questionnaire in Singapore. Paper presented at the annual meeting of the American educational Research Association, San Diego, CA.

Fisher, D., Fraser, B., \& Wubbels, T. (1993). Interpersonal teacher behavior and school environment. In T. Wubbels \& J. Levy (Eds.), Do you know what you look like? Interpersonal relationships in education (pp. 103-112). London, England: Falmer Press.

Fisher, D., Fraser, B., Wubbels, T., \& Brekelmans, M. (1993, April). Associations between school environment and teacher interpersonal behavior in the classroom. Paper presented at the annual meeting of the American Educational Research Association, Atlanta, GA.

Fisher, D., Rickards, T., \& Fraser, B. (1996). Assessing teacher-student interpersonal relationships in science classes. Australian Science Teachers Journal, 42, 28-33.

Fisher, D., \& Stolarchuk, E. (1997). The effects of using laptop computers on achievement, attitude to science and classroom environment in science. Paper presented at the Annual Conference of the Western Australian Science Education Association, Perth.

Fisher, D. L., Henderson, D., \& Fraser, B. J. (1995). Interpersonal behaviour in senior high school biology classes. Research in Science Education, 25(2), 125-133.

Fisher, D. L., \& Rickards, T. (1998). Associations between teacher-student interpersonal behaviour and student attitude to mathematics. Mathematics Education Research journal, 10(1), 3-15.

Fisher, D. L., Rickards, T., Goh, S. C., \& Wong, A. F. L. (1997). Perceptions of interpersonal teacher behaviour in secondary science classrooms in Singapore and Australia. Journal of Applied Research in Education, 1(2), 2-11.

Fraser, B.J. (1981). Test of Science-Related Attitudes. Melbourne: Australian Council for Educational Research.

Fraser, B. J. (1989). Assessing and improving classroom environment (What Research Says to the Science and Mathematics Teacher No. 2.). Perth: Key Centre for School Science and Mathematics, Curtin University of Technology.

Fraser, B. (1994). Research on classroom and school climate. In D. Gabel (Ed.), Handbook of research on science teaching and learning, (pp. 493-541). New York: Macmillan.

Fraser, B. J. (1998). science learning environments: assessment, effects and determinants. In K. G. Tobin (Ed.), The international handbook of science education (pp. 527-564). Dordrecht, The Netherlands: Kluwer Academic Publishers.

Fraser, B. J., \& Aldridge, J. M. (1998). The potential of cross-national studies of science classrooms; An example involving Australia and Taiwan. In M.Quigley (Ed.), Science, Mathematics and Technical Education for national Development. (pp. 7683). Brunei: University of Brunei Darussalam.

Fraser, B. J., Fisher, D. L., \& McRobbie, C. J. (1996). Development, validation and use of personal and class forms of a new classroom environment instrument. Paper presented at the Annual Meeting of the American Education Research Association, Chicago. 
Fraser, B., \& Walberg, H. (Eds.). (1991). Educational environments: Evaluation, antecedents and consequences. Oxford: Pergamon Press.

Getzel, J. W., \& Thelen, H. A. (1960). The classroom group as a unique social system. (Vol. 59): National Society for Studies in Education.

Hunus, R., \& Fraser, B. J. (1997). Chemistry learning Environment in Brunei Darussallam's Secondary Schools. In T. Rickards (Ed.), Science, Mathematics and Technology Education and national Development: Proceedings of the Vietnam Conference (pp. 108-120). Hanoi,Vietnam.

Khine, M. S., \& Fisher, D. L. (2001, December). Classroom environment and teacher's cultural background in secondary science classes in Asian context. Paper presented at the International Educational Research Conference of Australian association of Research in Education, Perth.

Khoo, H., \& Fraser, B. J. (1998). Using classroom environment dimensions in the evaluation of adult computer courses. Paper presented at the annual meeting of the National Association for Research in Science Teaching, San Diego, CA.

Kim, H., Fisher, D., \& Fraser, B. J. (2000). Classroom environment and teacher interpersonal behaviour in secondary classes in Korea. Evaluation and Research in Education, 14, 3-22.

Leary, T. (1957). An interpersonal diagnosis of personality. New York: Ronald-Press Company.

McRobbie, C. J., \& Fraser, B. J. (1993). Associations between student outcomes and psychosocial science environment. Journal of Educational Research, 87, 78-85.

Rawnsley, D. G. (1997). Associations between classroom learning environments, teacher interpersonal behaviours and student outcomes in secondary mathematics classrooms. Unpublished doctoral thesis, Curtin University of Technology, Perth, Western Australia

Santiboon, T. (2007). Associations between Students' Perceptions in Laboratory Learning Environments and Teacher Interpersonal Behaviours in Physics Classes in Thailand. Paper presented at The $1^{\text {st }}$ International Conference on Educational Reform 2007 November 9-11, 2007, Mahasarakham University, Thailand.

Taylor, P., Fraser, B., \& Fisher, D. (1997). Monitoring constructivist classroom learning environments. International Journal of Educational Research, 27(4), 293-302.

Teh, G., \& Fraser, B. (1995). Development and validation of an instrument for assessing the psychosocial environment of computer-assisted learning classrooms. Journal of Educational Computing Research, 12, 177-193.

Wahyudi. (2004). Educational practice and learning environments in rural and urban lower secondary science classrooms in Kalimantan Selatan Indonesia. Unplished doctoral thesis, Curtin University of Technology: Perth, Australia.

Waldrip, B. and Fisher, D. (2002). Student-teacher interactions and better science teachers. Queensland Journal of Educational Research, 18(2), 141-163. http://education.curtin.edu.au/iier/qjer/qjer18/waldrip.html

Watzlawick, P., Beavin, J., \& Jackson, D. (1967). The pragmatics of human communication. New York: Norton.

Wubbels, T. (1993). Teacher-student relationships in science and mathematics classes (What research says to the science and mathematics teacher, No. 11). Perth: National Key Centre for School Science and Mathematics, Curtin University of Technology.

Wubbels, T., Brekelmans, M. (1998), "The teacher factor in the social climate of the classroom", in Fraser, B.J., Tobin, K.G. (Eds), International Handbook of Science Education, Kluwer Academic Publishers, London, pp.565-80. 
Wubbels, T., Brekelmans, M., \& Hooymayers, H. (1991). Interpersonal teacher behavior in the classroom. In B. Fraser \& H. Walberg (Eds.), Educational environments: Evaluation, antecedents and consequences, (pp. 141-160). Oxford: Pergamon Press.

Wubbels, T., Creton, H., \& Holvast, A. (1988). Undesirable classroom situations. Interchange, 19, 25-40.

Wubbels, T., Creton, H., \& Hooymayers, H. (1985, April). Discipline problems of beginning teachers. Paper presented at annual meeting of American Educational Research Association, Chicago, IL.

Wubbels, T., \& Levy, J. (1991). A comparison of interpersonal behaviour of Dutch and American teachers. International Journal of Intercultural Relations, 15, 1-18.

Wubbels, T., \& Levy, J. (Eds.). (1993). Do you know what you look like? Interpersonal relationships in education. London, England: Falmer Press. 


\section{Appendix A}

\section{The Questionnaire on Teacher Interaction (QTI)}

The Questionnaire on Teacher Interaction (QTI) consists of 48 item asks you to describe the behaviour of your teacher. For each statement, draw a circle around the specific numeric value corresponding to how you feel about each statement. Please circle only ONE value per statement in both the Actual and Ideal/Preferred sections.

$$
\begin{aligned}
& 5=\text { Almost Always } \\
& 4=\text { Often } \\
& 3=\text { Sometimes } \\
& 2=\text { Seldom } \\
& 1=\text { Almost Never }
\end{aligned}
$$

For example:

\begin{tabular}{|l|l|l|l|l|l|l|l|l|l|l|l|}
\hline No & \multicolumn{1}{|c|}{ Statement } & \multicolumn{4}{c|}{ Actual } & \multicolumn{3}{|c|}{ Ideal/Preferred } \\
\hline 1 & $\begin{array}{l}\text { This teacher talks enthusiastically about her/his } \\
\text { subject. }\end{array}$ & 1 & 2 & 3 & 4 & 5 & 1 & 2 & 3 & 4 & 5 \\
\hline
\end{tabular}

If you think your teacher almost never talks enthusiastically about her/his subject, circle the 1 at the actual column. If you preferred that teacher should always talks enthusiastically about her/his subject, circle the 5 at Ideal/Preferred column. You also can choose the number 2, 3 and 4 which are in between.

\begin{tabular}{|l|l|l|l|l|l|l|l|l|l|l|l|l|}
\hline No & \multicolumn{1}{|c|}{ Statement } & \multicolumn{1}{|c|}{ Actual } & \multicolumn{5}{|c|}{ Ideal/Preferred } \\
\hline 1 & $\begin{array}{l}\text { This teacher talks enthusiastically about her/his } \\
\text { subject. }\end{array}$ & 1 & 2 & 3 & 4 & 5 & 1 & 2 & 3 & 4 & 5 \\
\hline 2 & This teacher explains things clearly. & 1 & 2 & 3 & 4 & 5 & 1 & 2 & 3 & 4 & 5 \\
\hline 3 & This teacher holds our attention. & 1 & 2 & 3 & 4 & 5 & 1 & 2 & 3 & 4 & 5 \\
\hline 4 & $\begin{array}{l}\text { This teacher knows everything that goes on in the } \\
\text { classroom. }\end{array}$ & 1 & 2 & 3 & 4 & 5 & 1 & 2 & 3 & 4 & 5 \\
\hline 5 & This teacher is a good leader. & 1 & 2 & 3 & 4 & 5 & 1 & 2 & 3 & 4 & 5 \\
\hline 6 & This teacher acts confidently. & 1 & 2 & 3 & 4 & 5 & 1 & 2 & 3 & 4 & 5 \\
\hline & & 1 & 2 & 3 & 4 & 5 & 1 & 2 & 3 & 4 & 5 \\
\hline 7 & This teacher helps us with our work. & 1 & 2 & 3 & 4 & 5 & 1 & 2 & 3 & 4 & 5 \\
\hline 8 & This teacher is friendly. & & & & & & & & & & & \\
\hline
\end{tabular}




\begin{tabular}{|c|c|c|c|c|c|c|c|c|c|c|c|}
\hline No & Statement & \multicolumn{5}{|c|}{ Actual } & \multicolumn{5}{|c|}{ Ideal/Preferred } \\
\hline 9 & This teacher is someone we can depend on. & 1 & 2 & 3 & 4 & 5 & 1 & 2 & 3 & 4 & 5 \\
\hline 10 & This teacher has a sense of humor. & 1 & 2 & 3 & 4 & 5 & 1 & 2 & 3 & 4 & 5 \\
\hline 11 & This teacher can take a joke. & 1 & 2 & 3 & 4 & 5 & 1 & 2 & 3 & 4 & 5 \\
\hline 12 & This teacher's class is pleasant. & 1 & 2 & 3 & 4 & 5 & 1 & 2 & 3 & 4 & 5 \\
\hline 13 & This teacher truts us. & 1 & 2 & 3 & 4 & 5 & 1 & 2 & 3 & 4 & 5 \\
\hline 14 & $\begin{array}{l}\text { If we don't agree with this teacher, we can talk } \\
\text { about it. }\end{array}$ & 1 & 2 & 3 & 4 & 5 & 1 & 2 & 3 & 4 & 5 \\
\hline 15 & This teacher is willing to explain things again. & 1 & 2 & 3 & 4 & 5 & 1 & 2 & 3 & 4 & 5 \\
\hline 16 & $\begin{array}{l}\text { If we have something to say, this teacher will } \\
\text { listen. }\end{array}$ & 1 & 2 & 3 & 4 & 5 & 1 & 2 & 3 & 4 & 5 \\
\hline 17 & This teacher realizes we do not understand. & 1 & 2 & 3 & 4 & 5 & 1 & 2 & 3 & 4 & 5 \\
\hline 18 & This teacher is patient. & 1 & 2 & 3 & 4 & 5 & 1 & 2 & 3 & 4 & 5 \\
\hline
\end{tabular}

\begin{tabular}{|l|l|l|l|l|l|l|l|l|l|l|l|}
\hline 19 & We can decide some things in this teacher's class. & 1 & 2 & 3 & 4 & 5 & 1 & 2 & 3 & 4 & 5 \\
\hline 20 & We can influence this teacher. & 1 & 2 & 3 & 4 & 5 & 1 & 2 & 3 & 4 & 5 \\
\hline 21 & This teacher lets us fool around in class. & 1 & 2 & 3 & 4 & 5 & 1 & 2 & 3 & 4 & 5 \\
\hline 22 & This teacher lets us get away with a lot in class. & 1 & 2 & 3 & 4 & 5 & 1 & 2 & 3 & 4 & 5 \\
\hline 23 & This teacher gives us a lot of free time in this class. & 1 & 2 & 3 & 4 & 5 & 1 & 2 & 3 & 4 & 5 \\
\hline 24 & This teacher is lenient. & 1 & 2 & 3 & 4 & 5 & 1 & 2 & 3 & 4 & 5 \\
\hline
\end{tabular}

\begin{tabular}{|l|l|l|l|l|l|l|l|l|l|l|l|}
\hline 25 & This teacher seems uncertain. & 1 & 2 & 3 & 4 & 5 & 1 & 2 & 3 & 4 & 5 \\
\hline 26 & This teacher is hesistant. & 1 & 2 & 3 & 4 & 5 & 1 & 2 & 3 & 4 & 5 \\
\hline 27 & $\begin{array}{l}\text { This teacher acts as if she/he does not know what } \\
\text { to do. }\end{array}$ & 1 & 2 & 3 & 4 & 5 & 1 & 2 & 3 & 4 & 5 \\
\hline 28 & This teacher let us boss him/her around. & 1 & 2 & 3 & 4 & 5 & 1 & 2 & 3 & 4 & 5 \\
\hline 29 & $\begin{array}{l}\text { This teacher is not sure what to do when we fool } \\
\text { around. }\end{array}$ & 1 & 2 & 3 & 4 & 5 & 1 & 2 & 3 & 4 & 5 \\
\hline 30 & It is easy to make a fool out of this teacher. & 1 & 2 & 3 & 4 & 5 & 1 & 2 & 3 & 4 & 5 \\
\hline
\end{tabular}

\begin{tabular}{|l|l|l|l|l|l|l|l|l|l|l|l|}
\hline 31 & This teacher thinks that we cheat. & 1 & 2 & 3 & 4 & 5 & 1 & 2 & 3 & 4 & 5 \\
\hline 32 & This teacher thinks that we don't know anything. & 1 & 2 & 3 & 4 & 5 & 1 & 2 & 3 & 4 & 5 \\
\hline 33 & This teacher puts us down. & 1 & 2 & 3 & 4 & 5 & 1 & 2 & 3 & 4 & 5 \\
\hline 34 & This teacher thinks that we cannot do things well. & 1 & 2 & 3 & 4 & 5 & 1 & 2 & 3 & 4 & 5 \\
\hline
\end{tabular}




\begin{tabular}{|c|c|c|c|c|c|c|c|c|c|c|c|}
\hline No & Statement & \multicolumn{5}{|c|}{ Actual } & \multicolumn{5}{|c|}{ Ideal/Preferred } \\
\hline 35 & This teacher seems dissatisfied. & 1 & 2 & 3 & 4 & 5 & 1 & 2 & 3 & 4 & 5 \\
\hline 36 & This teacher is suspicious. & 1 & 2 & 3 & 4 & 5 & 1 & 2 & 3 & 4 & 5 \\
\hline 37 & This teacher gets angry unexpectedly. & 1 & 2 & 3 & 4 & 5 & 1 & 2 & 3 & 4 & 5 \\
\hline 38 & This teacher gets angry quickly. & 1 & 2 & 3 & 4 & 5 & 1 & 2 & 3 & 4 & 5 \\
\hline 39 & $\begin{array}{l}\text { This teacher is too quick to correct us when we } \\
\text { break a rule. }\end{array}$ & 1 & 2 & 3 & 4 & 5 & 1 & 2 & 3 & 4 & 5 \\
\hline 40 & This teacher is impatient. & 1 & 2 & 3 & 4 & 5 & 1 & 2 & 3 & 4 & 5 \\
\hline 41 & It is easy to pick a fight whit this teacher. & 1 & 2 & 3 & 4 & 5 & 1 & 2 & 3 & 4 & 5 \\
\hline 42 & This teacher is sarcastic. & 1 & 2 & 3 & 4 & 5 & 1 & 2 & 3 & 4 & 5 \\
\hline 43 & This teacher is strict. & 1 & 2 & 3 & 4 & 5 & 1 & 2 & 3 & 4 & 5 \\
\hline 44 & We have to be silent in this teacher's class. & 1 & 2 & 3 & 4 & 5 & 1 & 2 & 3 & 4 & 5 \\
\hline 45 & This teacher's tests are hard. & 1 & 2 & 3 & 4 & 5 & 1 & 2 & 3 & 4 & 5 \\
\hline 46 & This teacher's standards are very high. & 1 & 2 & 3 & 4 & 5 & 1 & 2 & 3 & 4 & 5 \\
\hline 47 & This teacher is severe when marking papers. & 1 & 2 & 3 & 4 & 5 & 1 & 2 & 3 & 4 & 5 \\
\hline 48 & We are afraid of this teacher. & 1 & 2 & 3 & 4 & 5 & 1 & 2 & 3 & 4 & 5 \\
\hline
\end{tabular}




\section{Appendix B}

\section{What Is Happening In this Classroom (WIHIC) Questionnaire}

\section{Directions}

This questionnaire has 42 sentences and asks you to describe your classroom learning environment. This is NOT a test. Your opinion is what is wanted.

For each statement, draw a circle around the specific numeric value corresponding to how you feel about each statement. Please circle only ONE value per statement in both the Actual and Ideal/Preferred sections.

$$
\begin{aligned}
& 4=\text { Almost Always } \\
& 3=\text { Often } \\
& 2=\text { Sometimes } \\
& 1=\text { Seldom } \\
& 0=\text { Almost Never }
\end{aligned}
$$

For example:

\begin{tabular}{|l|l|l|l|l|l|l|l|l|l|l|l|}
\hline No & \multicolumn{3}{|c|}{ Statement } & \multicolumn{5}{|c|}{ Actual } & \multicolumn{3}{|c|}{ Ideal/Preferred } \\
\hline 12 & $\begin{array}{l}\text { The teacher moves about the class to talk with } \\
\text { me }\end{array}$ & 0 & 1 & 2 & 3 & 4 & 0 & 1 & 2 & 3 & 4 \\
\hline
\end{tabular}

If you think that your teacher never moves about the class to talk with you, circle the 0 at the actual column. If you preferred that teacher should always help you when you have trouble with the work, circle the 4 at Ideal/Preferred column. You also can choose the number 1, 2, and 3 which are in between.

\begin{tabular}{|l|l|l|l|l|l|l|l|l|l|l|l|}
\hline No & \multicolumn{1}{|c|}{ Statement } & \multicolumn{4}{|c|}{ Actual } & \multicolumn{3}{|c|}{ Ideal/Preferred } \\
\hline 1 & I make friendships among students in this class & 0 & 1 & 2 & 3 & 4 & 0 & 1 & 2 & 3 & 4 \\
\hline 2 & I know other students in this class & 0 & 1 & 2 & 3 & 4 & 0 & 1 & 2 & 3 & 4 \\
\hline 3 & I am friendly to members of this class & 0 & 1 & 2 & 3 & 4 & 0 & 1 & 2 & 3 & 4 \\
\hline 4 & Members of the class are my friends & 0 & 1 & 2 & 3 & 4 & 0 & 1 & 2 & 3 & 4 \\
\hline 5 & I work well with other class members & 0 & 1 & 2 & 3 & 4 & 0 & 1 & 2 & 3 & 4 \\
\hline 6 & Students in this class like me & 0 & 1 & 2 & 3 & 4 & 0 & 1 & 2 & 3 & 4 \\
\hline
\end{tabular}




\begin{tabular}{|c|c|c|c|c|c|c|c|c|c|c|c|}
\hline No & Statement & \multicolumn{5}{|c|}{ Actual } & \multicolumn{5}{|c|}{ Ideal/Preferred } \\
\hline 7 & The teacher takes a personal interest in me & 0 & 1 & 2 & 3 & 4 & 0 & 1 & 2 & 3 & 4 \\
\hline 8 & The teacher goes out of his / her way to help me & 0 & 1 & 2 & 3 & 4 & 0 & 1 & 2 & 3 & 4 \\
\hline 9 & The teacher considers my feelings & 0 & 1 & 2 & 3 & 4 & 0 & 1 & 2 & 3 & 4 \\
\hline 10 & $\begin{array}{l}\text { The teacher helps me when I have trouble with } \\
\text { the work }\end{array}$ & 0 & 1 & 2 & 3 & 4 & 0 & 1 & 2 & 3 & 4 \\
\hline 11 & The teacher is interested in my problems & 0 & 1 & 2 & 3 & 4 & 0 & 1 & 2 & 3 & 4 \\
\hline 12 & $\begin{array}{l}\text { The teacher moves about the class to talk with } \\
\text { me }\end{array}$ & 0 & 1 & 2 & 3 & 4 & 0 & 1 & 2 & 3 & 4 \\
\hline 13 & I discuss ideas in class & 0 & 1 & 2 & 3 & 4 & 0 & 1 & 2 & 3 & 4 \\
\hline 14 & I give my opinion during the class discussions & 0 & 1 & 2 & 3 & 4 & 0 & 1 & 2 & 3 & 4 \\
\hline 15 & The teacher asks me questions & 0 & 1 & 2 & 3 & 4 & 0 & 1 & 2 & 3 & 4 \\
\hline 16 & I ask the teacher questions & 0 & 1 & 2 & 3 & 4 & 0 & 1 & 2 & 3 & 4 \\
\hline 17 & I explain my ideas to other students & 0 & 1 & 2 & 3 & 4 & 0 & 1 & 2 & 3 & 4 \\
\hline 18 & I am asked to explain how I solve problems & 0 & 1 & 2 & 3 & 4 & 0 & 1 & 2 & 3 & 4 \\
\hline 19 & I carry out investigations to test my ideas & 0 & 1 & 2 & 3 & 4 & 0 & 1 & 2 & 3 & 4 \\
\hline 20 & $\begin{array}{l}\text { I am asked to think about the evidence for my } \\
\text { statements }\end{array}$ & 0 & 1 & 2 & 3 & 4 & 0 & 1 & 2 & 3 & 4 \\
\hline 21 & $\begin{array}{l}\text { I explain the meaning of statement, diagram, } \\
\text { and graphs }\end{array}$ & 0 & 1 & 2 & 3 & 4 & 0 & 1 & 2 & 3 & 4 \\
\hline 22 & $\begin{array}{l}\text { I carry out investigation to answer question that } \\
\text { puzzle me }\end{array}$ & 0 & 1 & 2 & 3 & 4 & 0 & 1 & 2 & 3 & 4 \\
\hline 23 & $\begin{array}{l}\text { I carry out investigations to answer the teachers' } \\
\text { questions }\end{array}$ & 0 & 1 & 2 & 3 & 4 & 0 & 1 & 2 & 3 & 4 \\
\hline 24 & $\begin{array}{l}\text { I find out the answers to questions by doing } \\
\text { investigations }\end{array}$ & 0 & 1 & 2 & 3 & 4 & 0 & 1 & 2 & 3 & 4 \\
\hline 25 & I do as much as I set out to do & 0 & 1 & 2 & 3 & 4 & 0 & 1 & 2 & 3 & 4 \\
\hline 26 & I know the goals for this class & 0 & 1 & 2 & 3 & 4 & 0 & 1 & 2 & 3 & 4 \\
\hline
\end{tabular}




\begin{tabular}{|c|c|c|c|c|c|c|c|c|c|c|c|}
\hline No & Statement & \multicolumn{5}{|c|}{ Actual } & \multicolumn{5}{|c|}{ Ideal/Preferred } \\
\hline 27 & I am ready to start this class on time & 0 & 1 & 2 & 3 & 4 & 0 & 1 & 2 & 3 & 4 \\
\hline 28 & I pay attention during this class & 0 & 1 & 2 & 3 & 4 & 0 & 1 & 2 & 3 & 4 \\
\hline 29 & I try to understand the work in this class & 0 & 1 & 2 & 3 & 4 & 0 & 1 & 2 & 3 & 4 \\
\hline 30 & I know how much work I have to do & 0 & 1 & 2 & 3 & 4 & 0 & 1 & 2 & 3 & 4 \\
\hline 31 & $\begin{array}{l}\text { I cooperate with other students when doing } \\
\text { assignment work }\end{array}$ & 0 & 1 & 2 & 3 & 4 & 0 & 1 & 2 & 3 & 4 \\
\hline 32 & $\begin{array}{l}\text { When I work in a group in the class, there is } \\
\text { teamwork }\end{array}$ & 0 & 1 & 2 & 3 & 4 & 0 & 1 & 2 & 3 & 4 \\
\hline 33 & $\begin{array}{l}\text { I work with other students on projects in this } \\
\text { class }\end{array}$ & 0 & 1 & 2 & 3 & 4 & 0 & 1 & 2 & 3 & 4 \\
\hline 34 & I learn from other students in this class & 0 & 1 & 2 & 3 & 4 & 0 & 1 & 2 & 3 & 4 \\
\hline 35 & I work with other students in this class & 0 & 1 & 2 & 3 & 4 & 0 & 1 & 2 & 3 & 4 \\
\hline 36 & $\begin{array}{l}\text { I cooperate with other students on class } \\
\text { activities }\end{array}$ & 0 & 1 & 2 & 3 & 4 & 0 & 1 & 2 & 3 & 4 \\
\hline 37 & $\begin{array}{l}\text { The teacher gives us much attention to my } \\
\text { questions as to other students' questions }\end{array}$ & 0 & 1 & 2 & 3 & 4 & 0 & 1 & 2 & \begin{tabular}{|l|}
3 \\
\end{tabular} & 4 \\
\hline 38 & $\begin{array}{l}\text { I have the same amount of say in this class as } \\
\text { other students }\end{array}$ & 0 & 1 & 2 & 3 & 4 & 0 & 1 & 2 & 3 & 4 \\
\hline 39 & $\begin{array}{l}\text { I am treated the same as other students in this } \\
\text { class }\end{array}$ & 0 & 1 & 2 & 3 & 4 & 0 & 1 & 2 & 3 & 4 \\
\hline 40 & $\begin{array}{l}\text { I get the same opportunity to contribute to class } \\
\text { discussions as the other students }\end{array}$ & 0 & 1 & 2 & 3 & 4 & 0 & 1 & 2 & 3 & 4 \\
\hline 41 & $\begin{array}{l}\text { My work receives as much praise as other } \\
\text { students' work }\end{array}$ & 0 & 1 & 2 & 3 & 4 & 0 & 1 & 2 & 3 & 4 \\
\hline 42 & $\begin{array}{l}\text { I get the same opportunity to answer questions } \\
\text { as other students }\end{array}$ & 0 & 1 & 2 & 3 & 4 & 0 & 1 & 2 & 3 & 4 \\
\hline
\end{tabular}

Thank you for your cooperation 


\section{Appendix C}

The Indonesian version The Questionnaire on Teacher Interaction (QTI)

\section{Kuisioner Interaksi Guru dengan Siswa}

\section{Petunjuk Umum}

Kuisioner ini berisi pernyataan-pernyataan tentang kegiatan atau kejadian yang muncul di dalam kelas. Anda diminta untuk memikirkan dan menjawab pertanyaan sejauh mana kegiatan atau kejadian tersebut berlangsung selama proses kegiatan belajar dan mengajar (KBM) untuk bidang studi Matematika. Di sini tidak ada jawaban benar atau salah. Pendapat andalah yang diinginkan.

\section{Informasi diri dan sekolah}

\begin{tabular}{|l|l|l|}
\hline Nama Sekolah & \multicolumn{2}{|l|}{} \\
\hline $\begin{array}{l}\text { Nilai Rerata Ulangan } \\
\text { Matematika }\end{array}$ & \\
\hline $\begin{array}{l}\text { Nama Guru } \\
\text { Pengajar }\end{array}$ & \\
\hline
\end{tabular}

\begin{tabular}{|c|c|c|}
\hline \multicolumn{3}{|l|}{ Nama Siswa } \\
\hline Kelas & & \\
\hline $\begin{array}{l}\text { Jenis } \\
\text { Kelamin }\end{array}$ & Laki-laki & Perempuan \\
\hline
\end{tabular}

Kuisioner Interaksi Guru dengan Siswa, terdiri dari 48 pernyataan tentang sikap, tindakan and interaksi guru dengan siswa di kelas, dan lembar jawaban di samping pernyataan. Pada kolom jawaban ada 2 macam, yaitu untuk jawaban keadaan yang sebenarnya dan jawaban untuk keadaan yang diinginkan . Untuk mengisi bagian kedua ini, lingkarilah angka pada kolom-kolom jawaban sebagai berikut:

1 jika kegiatan/kejadian/praktek

2 jika kegiatan/kejadian/praktek

3 jika kegiatan/kejadian/praktek

4 jika kegiatan/kejadian/praktek

5 jika kegiatan/kejadian/praktek hampir tidak pernah,

jarang-jarang,

kadang-kadang,

sering kali, atau

hampir selalu berlangsung.

Jika anda berubah pikiran dan ingin mengganti jawaban, silanglah jawaban tersebut dan lingkari untuk jawaban yang baru. 


\section{Contoh:}

Misalnya, untuk pernyataan no 1 , anda diminta memberikan pendapat tentang pernyataan 'Guru menjelaskan materi pelajaran dengan antusias'. Jika anda merasa hal tersebut pada kenyataannya 'jarang-jarang' terjadi, maka lingkarilah angka 2 pada kolom jawaban 'keadaan sebenarnya/aktual'. Dan jika anda menginginkan hal tersebut akan sering berlangsung, maka lingkarilah angka 4 pada kolom jawaban 'Keadaan yang diinginkan' .

\begin{tabular}{|l|l|c|c|c|c|c|c|c|c|c|c|}
\hline No & \multicolumn{1}{|c|}{ Pernyataan } & \multicolumn{3}{|c|}{ Sebenarnya } & \multicolumn{3}{|c|}{ Ideal/Diinginkan } \\
\hline 1 & $\begin{array}{l}\text { Guru menjelaskan materi pelajaran dengan } \\
\text { antusias }\end{array}$ & 1 & 2 & 3 & 4 & 5 & 1 & 2 & 3 & 4 & 5 \\
\hline
\end{tabular}

\section{Kuisioner Interaksi Guru dengan Siswa}

\begin{tabular}{|c|c|c|c|c|c|c|c|c|c|c|c|}
\hline No & Pernyataan & \multicolumn{5}{|c|}{ Sebenarnya } & \multicolumn{5}{|c|}{ Ideal/Diinginkan } \\
\hline 1 & $\begin{array}{l}\text { Guru ini menjelaskan materi pelajaran dengan } \\
\text { antusias }\end{array}$ & 1 & 2 & 3 & 4 & 5 & 1 & 2 & 3 & 4 & 5 \\
\hline 2 & Guru ini menjelaskan materi pelajaran dengan jelas & 1 & 2 & 3 & 4 & 5 & 1 & 2 & 3 & 4 & 5 \\
\hline 3 & Guru ini dapat menarik perhatian siswa & 1 & 2 & 3 & 4 & 5 & 1 & 2 & 3 & 4 & 5 \\
\hline 4 & $\begin{array}{l}\text { Guru ini memahami apa yang berlaku di dalam } \\
\text { kelas ini }\end{array}$ & 1 & 2 & 3 & 4 & 5 & 1 & 2 & 3 & 4 & 5 \\
\hline 5 & Guru ini adalah pemimpin yang baik & 1 & 2 & 3 & 4 & 5 & 1 & 2 & 3 & 4 & 5 \\
\hline 6 & Guru ini sangat percaya diri dalam mengajar & 1 & 2 & 3 & 4 & 5 & 1 & 2 & 3 & 4 & 5 \\
\hline 7 & $\begin{array}{l}\text { Guru ini mau membantu siswa dalam mebuat } \\
\text { tugas-tugas. }\end{array}$ & 1 & 2 & 3 & 4 & 5 & 1 & 2 & 3 & 4 & 5 \\
\hline 8 & Guru ini ramah dan bersahabat & 1 & 2 & 3 & 4 & 5 & 1 & 2 & 3 & 4 & 5 \\
\hline 9 & $\begin{array}{l}\text { Guru ini dapat menjadi tempat curahan hati } \\
\text { (curhat) }\end{array}$ & 1 & 2 & 3 & 4 & 5 & 1 & 2 & 3 & 4 & 5 \\
\hline 10 & Guru ini punya selera humor & 1 & 2 & 3 & 4 & 5 & 1 & 2 & 3 & 4 & 5 \\
\hline 11 & Guru ini dapat diajak bercanda & 1 & 2 & 3 & 4 & 5 & 1 & 2 & 3 & 4 & 5 \\
\hline 12 & Kelas yang diampu guru ini sangat menyenangkan & 1 & 2 & 3 & 4 & 5 & 1 & 2 & 3 & 4 & 5 \\
\hline 13 & Guru ini yakin dan percaya terhadap siswa & 1 & 2 & 3 & 4 & 5 & 1 & 2 & 3 & 4 & 5 \\
\hline 14 & $\begin{array}{l}\text { Jika kami tidak setuju, kami dapat berunding } \\
\text { dengan guru ini }\end{array}$ & 1 & 2 & 3 & 4 & 5 & 1 & 2 & 3 & 4 & 5 \\
\hline 15 & Guru ini mau menjelaskan ulang jika diminta siswa & 1 & 2 & 3 & 4 & 5 & 1 & 2 & 3 & 4 & 5 \\
\hline
\end{tabular}




\begin{tabular}{|c|c|c|c|c|c|c|c|c|c|c|c|}
\hline No & Pernyataan & \multicolumn{5}{|c|}{ Sebenarnya } & \multicolumn{5}{|c|}{ Ideal/Diinginkan } \\
\hline 16 & $\begin{array}{l}\text { Guru ini mau mendengar jika siswa mengajukan } \\
\text { pendapat }\end{array}$ & 1 & 2 & 3 & 4 & 5 & 1 & 2 & 3 & 4 & 5 \\
\hline 17 & $\begin{array}{l}\text { Guru ini mengetahui ketika kita tidak memahami } \\
\text { pelajaran }\end{array}$ & 1 & 2 & 3 & 4 & 5 & 1 & 2 & 3 & 4 & 5 \\
\hline 18 & Guru ini penyabar & 1 & 2 & 3 & 4 & 5 & 1 & 2 & 3 & 4 & 5 \\
\hline 19 & $\begin{array}{l}\text { Siswa dapat membuat keputusan di dalam kelas } \\
\text { guru ini }\end{array}$ & 1 & 2 & 3 & 4 & 5 & 1 & 2 & 3 & 4 & 5 \\
\hline 20 & Siswa dapat mempengaruhi guru ini & 1 & 2 & 3 & 4 & 5 & 1 & 2 & 3 & 4 & 5 \\
\hline 21 & $\begin{array}{l}\text { Guru ini membiarkan siswa main-main di dalam } \\
\text { kelas }\end{array}$ & 1 & 2 & 3 & 4 & 5 & 1 & 2 & 3 & 4 & 5 \\
\hline 22 & $\begin{array}{l}\text { Guru ini sangat longgar terhadap sikap siswa di } \\
\text { kelas }\end{array}$ & 1 & 2 & 3 & 4 & 5 & 1 & 2 & 3 & 4 & 5 \\
\hline 23 & $\begin{array}{l}\text { Guru ini memberi banyak waktu luang kepada } \\
\text { siswa di kelas }\end{array}$ & 1 & 2 & 3 & 4 & 5 & 1 & 2 & 3 & 4 & 5 \\
\hline 24 & Guru ini sangat rileks & 1 & 2 & 3 & 4 & 5 & 1 & 2 & 3 & 4 & 5 \\
\hline 25 & Guru ini kelihatan tidak percaya diri di depan kelas & 1 & 2 & 3 & 4 & 5 & 1 & 2 & 3 & 4 & 5 \\
\hline 26 & Guru ini kelihatan ragu-ragu & 1 & 2 & 3 & 4 & 5 & 1 & 2 & 3 & 4 & 5 \\
\hline 27 & $\begin{array}{l}\text { Guru ini seolah-olah tidak tahu apa yang harus } \\
\text { dilakukan }\end{array}$ & 1 & 2 & 3 & 4 & 5 & 1 & 2 & 3 & 4 & 5 \\
\hline 28 & $\begin{array}{l}\text { Guru ini membiarkan siswa menentukan kegiatan } \\
\text { kelas }\end{array}$ & 1 & 2 & 3 & 4 & 5 & 1 & 2 & 3 & 4 & 5 \\
\hline 29 & $\begin{array}{l}\text { Guru tidak tahu apa yang dibuat jika siswa } \\
\text { bergurau }\end{array}$ & 1 & 2 & 3 & 4 & 5 & 1 & 2 & 3 & 4 & 5 \\
\hline 30 & $\begin{array}{l}\text { Mudah bagi siswa untuk membuat kacau di kelas } \\
\text { guru ini }\end{array}$ & 1 & 2 & 3 & 4 & 5 & 1 & 2 & 3 & 4 & 5 \\
\hline 31 & $\begin{array}{l}\text { Guru ini berprasangka bahwa siswa-siswanya } \\
\text { curang }\end{array}$ & 1 & 2 & 3 & 4 & 5 & 1 & 2 & 3 & 4 & 5 \\
\hline 32 & Guru ini menganggap siswanya tidak tahu apa-apa & 1 & 2 & 3 & 4 & 5 & 1 & 2 & 3 & 4 & 5 \\
\hline 33 & Guru ini meremehkan dan mengecewakan siswa & 1 & 2 & 3 & 4 & 5 & 1 & 2 & 3 & 4 & 5 \\
\hline 34 & $\begin{array}{l}\text { Guru ini menganggap siswa tidak dapat berbuat } \\
\text { dengan baik }\end{array}$ & 1 & 2 & 3 & 4 & 5 & 1 & 2 & 3 & 4 & 5 \\
\hline
\end{tabular}




\begin{tabular}{|c|c|c|c|c|c|c|c|c|c|c|c|}
\hline No & Pernyataan & \multicolumn{5}{|c|}{ Sebenarnya } & \multicolumn{5}{|c|}{ Ideal/Diinginkan } \\
\hline 35 & Guru ini kelihatan frustasi/kecewa & 1 & 2 & 3 & 4 & 5 & 1 & 2 & 3 & 4 & 5 \\
\hline 36 & Guru ini kelihatan curiga/tidak mempercayai siswa & 1 & 2 & 3 & 4 & 5 & 1 & 2 & 3 & 4 & 5 \\
\hline 37 & Guru ini bias marah dengan tiba-tiba & 1 & 2 & 3 & 4 & 5 & 1 & 2 & 3 & 4 & 5 \\
\hline 38 & Guru ini mudah sekali marah & 1 & 2 & 3 & 4 & 5 & 1 & 2 & 3 & 4 & 5 \\
\hline 39 & $\begin{array}{l}\text { Guru ini segera saja ngomel jika siswa melanggar } \\
\text { tatib kelas }\end{array}$ & 1 & 2 & 3 & 4 & 5 & 1 & 2 & 3 & 4 & 5 \\
\hline 40 & Guru ini tidak penyabar & 1 & 2 & 3 & 4 & 5 & 1 & 2 & 3 & 4 & 5 \\
\hline 41 & Sangat mudah untuk bersitegang dengan guru ini & 1 & 2 & 3 & 4 & 5 & 1 & 2 & 3 & 4 & 5 \\
\hline 42 & Guru ini sinis terhadap siswa & 1 & 2 & 3 & 4 & 5 & 1 & 2 & 3 & 4 & 5 \\
\hline 43 & Guru ini tegas & 1 & 2 & 3 & 4 & 5 & 1 & 2 & 3 & 4 & 5 \\
\hline 44 & Siswa harus diam dan senyap di kelas guru ini & 1 & 2 & 3 & 4 & 5 & 1 & 2 & 3 & 4 & 5 \\
\hline 45 & Ulangan/tes yang diberikan guru ini sangat sulit & 1 & 2 & 3 & 4 & 5 & 1 & 2 & 3 & 4 & 5 \\
\hline 46 & Standar nilai di kelas guru ini sangat tinggi & 1 & 2 & 3 & 4 & 5 & 1 & 2 & 3 & 4 & 5 \\
\hline 47 & Guru ini killer dalam memberi nilai & 1 & 2 & 3 & 4 & 5 & 1 & 2 & 3 & 4 & 5 \\
\hline 48 & Siswa takut terhadap guru ini & 1 & 2 & 3 & 4 & 5 & 1 & 2 & 3 & 4 & 5 \\
\hline
\end{tabular}

\section{Terima Kasih}




\section{Appendix D}

\section{The Indonesian version of What Is Happening In this Classroom (WIHIC) Questionnaire (Full version)}

\section{Kuisioner Suasana Belajar di Kelasku}

\section{Petunjuk Umum}

Kuisioner ini berisi pernyataan-pernyataan tentang kegiatan atau kejadian yang muncul di dalam kelas. Anda diminta untuk memikirkan dan menjawab pertanyaan sejauh mana kegiatan atau kejadian tersebut berlangsung selama proses kegiatan belajar dan mengajar (KBM) untuk bidang studi Matematika. Di sini tidak ada jawaban benar atau salah. Pendapat andalah yang diinginkan.

\section{Informasi diri dan sekolah}

\begin{tabular}{|l|l|}
\hline Nama Sekolah & \multicolumn{2}{|l|}{} \\
Nilai Rerata Ulangan & \\
Matematika & \\
\hline Nama Guru & \\
Pengajar & \\
\hline
\end{tabular}

\begin{tabular}{|l|l|l|l|l|}
\hline Nama Siswa & \multicolumn{2}{|l|}{} \\
\hline Kelas & \multicolumn{2}{|l|}{} \\
\hline $\begin{array}{l}\text { Jenis } \\
\text { Kelamin }\end{array}$ & & Laki-laki & & Perempuan \\
\hline
\end{tabular}

Kuisioner ini, Suasana Belajar di Kelasku, berisi 56 pernyataan tentang kegiatan atau praktek yang muncul di dalam kelas dan lembar jawaban di samping pernyataan. Pada kolom jawaban ada 2 macam, yaitu untuk jawaban keadaan yang sebenarnya dan jawaban untuk keadaan yang diinginkan . Untuk mengisi bagian kedua ini, lingkarilah angka pada kolomkolom jawaban sebagai berikut:

1 jika kegiatan/kejadian/praktek

2 jika kegiatan/kejadian/praktek

$3 \quad$ jika kegiatan/kejadian/praktek

$4 \quad$ jika kegiatan/kejadian/praktek

$5 \quad$ jika kegiatan/kejadian/praktek

\section{hampir tidak pernah,} jarang-jarang, kadang-kadang, sering kali, atau hampir selalu berlangsung.

Jika anda berubah pikiran dan ingin mengganti jawaban, silanglah jawaban tersebut dan lingkari untuk jawaban yang baru. 


\section{Contoh:}

Misalnya, untuk no 1, anda diminta memberikan pendapat tentang pernyataan 'Saya berkawan dengan semua siswa di kelas ini’. Jika anda merasa hal tersebut pada kenyataannya 'kadang-kadang' terjadi, maka anda melingkari angka 3 pada kolom jawaban 'keadaan sebenarnya/aktual'. Dan jika anda menginginkan hal tersebut hampir selalu berlangsung, maka lingkarilah angka 5 pada kolom jawaban 'Keadaan yang diinginkan'.

\begin{tabular}{|l|l|c|c|c|c|c|c|c|c|c|}
\hline No & Pernyataan & \multicolumn{4}{|c|}{ Sebenarnya } & \multicolumn{4}{|c|}{ Ideal/Diinginkan } \\
\hline 1 & Saya berkawan dengan semua siswa di kelas ini & 1 & 2 & 3 & 4 & 5 & 1 & 2 & 3 & 4 \\
\hline
\end{tabular}

\section{Kuisioner Suasana Belajar di Kelasku}

\begin{tabular}{|c|c|c|c|c|c|c|c|c|c|c|c|}
\hline No & Pernyataan & \multicolumn{5}{|c|}{ Sebenarnya } & \multicolumn{5}{|c|}{ Ideal/Diinginkan } \\
\hline 1 & Saya berkawan dengan semua siswa di kelas ini. & 1 & 2 & 3 & 4 & 5 & 1 & 2 & 3 & 4 & 5 \\
\hline 2 & Saya kenal semua siswa di kelas ini. & 1 & 2 & 3 & 4 & 5 & 1 & 2 & 3 & 4 & 5 \\
\hline 3 & Saya ramah terhadap anggota kelas ini. & 1 & 2 & 3 & 4 & 5 & 1 & 2 & 3 & 4 & 5 \\
\hline 4 & Siswa-siswa anggota kelas ini adalah teman saya. & 1 & 2 & 3 & 4 & 5 & 1 & 2 & 3 & 4 & 5 \\
\hline 5 & $\begin{array}{l}\text { Saya bekerjasama dengan baik dengan anggota } \\
\text { kelas ini. }\end{array}$ & 1 & 2 & 3 & 4 & 5 & 1 & 2 & 3 & 4 & 5 \\
\hline 6 & $\begin{array}{l}\text { Saya menolong teman yang mempunyai kesulitan } \\
\text { dengan tugas mereka. }\end{array}$ & 1 & 2 & 3 & 4 & 5 & 1 & 2 & 3 & 4 & 5 \\
\hline 7 & Siswa-siswa di kelas ini menyukai saya. & 1 & 2 & 3 & 4 & 5 & 1 & 2 & 3 & 4 & 5 \\
\hline 8 & $\begin{array}{l}\text { Di kelas ini saya mendapat pertolongan dari siswa } \\
\text { lainnya. }\end{array}$ & 1 & 2 & 3 & 4 & 5 & 1 & 2 & 3 & 4 & 5 \\
\hline 9 & $\begin{array}{l}\text { Bapak/ibu guru dapat menarik perhatian saya } \\
\text { secara khusus. }\end{array}$ & 1 & 2 & 3 & 4 & 5 & 1 & 2 & 3 & 4 & 5 \\
\hline 10 & Bapak/ibu guru menolong saya secara khusus. & 1 & 2 & 3 & 4 & 5 & 1 & 2 & 3 & 4 & 5 \\
\hline 11 & Bapak/ibu guru menghargai perasaan saya. & 1 & 2 & 3 & 4 & 5 & 1 & 2 & 3 & 4 & 5 \\
\hline 12 & $\begin{array}{l}\text { Bapak/ibu guru menolong saya ketika saya } \\
\text { mendapat kesulitan dalam menyelesaikan } \\
\text { pekerjaan saya. }\end{array}$ & 1 & 2 & 3 & 4 & 5 & 1 & 2 & 3 & 4 & 5 \\
\hline 13 & Bapak/ibu guru berbicara kepada saya. & 1 & 2 & 3 & 4 & 5 & 1 & 2 & 3 & 4 & 5 \\
\hline
\end{tabular}




\begin{tabular}{|c|c|c|c|c|c|c|c|c|c|c|c|}
\hline No & Pernyataan & \multicolumn{5}{|c|}{ Sebenarnya } & \multicolumn{5}{|c|}{ Ideal/Diinginkan } \\
\hline 14 & $\begin{array}{l}\text { Bapak/ibu guru tertarik dengan masalah/kesulitan } \\
\text { saya. }\end{array}$ & 1 & 2 & 3 & 4 & 5 & 1 & 2 & 3 & 4 & 5 \\
\hline 15 & $\begin{array}{l}\text { Bapak/ibu guru berkeliling di kelas dan dapat } \\
\text { berbicara kepada saya. }\end{array}$ & 1 & 2 & 3 & 4 & 5 & 1 & 2 & 3 & 4 & 5 \\
\hline 16 & $\begin{array}{l}\text { Pertanyaan Bpk/Ibu guru membantu saya untuk } \\
\text { memahami pelajaran }\end{array}$ & 1 & 2 & 3 & 4 & 5 & 1 & 2 & 3 & 4 & 5 \\
\hline 17 & \begin{tabular}{|l|} 
Saya mendiskusikan ide-ide atau gagasan-gagasan. \\
.
\end{tabular} & 1 & 2 & 3 & 4 & 5 & 1 & 2 & 3 & 4 & 5 \\
\hline 18 & $\begin{array}{l}\text { Saya memberikan pendapat saya selama diskusi } \\
\text { kelas berlangsung. }\end{array}$ & 1 & 2 & 3 & 4 & 5 & 1 & 2 & 3 & 4 & 5 \\
\hline 19 & $\begin{array}{l}\text { Bapak/ibu guru mengajukan pertanyaan kepada } \\
\text { saya. }\end{array}$ & 1 & 2 & 3 & 4 & 5 & 1 & 2 & 3 & 4 & 5 \\
\hline 20 & $\begin{array}{l}\text { Ide-ide dan saran-saran saya dipakai selama } \\
\text { diskusi berlangsung. }\end{array}$ & 1 & 2 & 3 & 4 & 5 & 1 & 2 & 3 & 4 & 5 \\
\hline 21 & $\begin{array}{l}\text { Saya mengajukan pertanyaan kepada bapak/ibu } \\
\text { guru. }\end{array}$ & 1 & 2 & 3 & 4 & 5 & 1 & 2 & 3 & 4 & 5 \\
\hline 22 & Saya menerangkan ide saya kepada siswa lainnya. & 1 & 2 & 3 & 4 & 5 & 1 & 2 & 3 & 4 & 5 \\
\hline 23 & $\begin{array}{l}\text { Teman-teman mau berdiskusi dengan saya tentang } \\
\text { pelajaran }\end{array}$ & 1 & 2 & 3 & 4 & 5 & 1 & 2 & 3 & 4 & 5 \\
\hline 24 & $\begin{array}{l}\text { Saya diminta untuk menerangkan cara } \\
\text { menyelesaikan suatu masalah. }\end{array}$ & 1 & 2 & 3 & 4 & 5 & 1 & 2 & 3 & 4 & 5 \\
\hline 25 & $\begin{array}{l}\text { Saya melakukan penyelidikan untuk menguji/men- } \\
\text { test ide-ide saya. }\end{array}$ & 1 & 2 & 3 & 4 & 5 & 1 & 2 & 3 & 4 & 5 \\
\hline 26 & $\begin{array}{l}\text { Saya diminta memikirkan fakta-fakta pendukung } \\
\text { suatu pernyataan. }\end{array}$ & 1 & 2 & 3 & 4 & 5 & 1 & 2 & 3 & 4 & 5 \\
\hline 27 & $\begin{array}{l}\text { Saya melakukan penyelidikan untuk menjawab } \\
\text { pertanyaan yang muncul dari diskusi-diskusi kelas. }\end{array}$ & 1 & 2 & 3 & 4 & 5 & 1 & 2 & 3 & 4 & 5 \\
\hline 28 & $\begin{array}{l}\text { Saya menjelaskan arti dari suatu pernyataan, } \\
\text { diagram dan grafik. }\end{array}$ & 1 & 2 & 3 & 4 & 5 & 1 & 2 & 3 & 4 & 5 \\
\hline 29 & $\begin{array}{l}\text { Saya melakukan penyelidikan untuk menjawab } \\
\text { pertanyaan yang menjadi teka-teki atau masalah } \\
\text { bagi saya. }\end{array}$ & 1 & 2 & 3 & 4 & 5 & 1 & 2 & 3 & 4 & 5 \\
\hline
\end{tabular}




\begin{tabular}{|c|c|c|c|c|c|c|c|c|c|c|c|}
\hline No & Pernyataan & \multicolumn{5}{|c|}{ Sebenarnya } & \multicolumn{5}{|c|}{ Ideal/Diinginkan } \\
\hline 30 & $\begin{array}{l}\text { Saya melakukan penyelidikan untuk menjawab } \\
\text { pertanyaan guru. }\end{array}$ & 1 & 2 & 3 & 4 & 5 & 1 & 2 & 3 & 4 & 5 \\
\hline 31 & $\begin{array}{l}\text { Saya menemukan jawaban suatu masalah melalui } \\
\text { penyelidikan. }\end{array}$ & 1 & 2 & 3 & 4 & 5 & 1 & 2 & 3 & 4 & 5 \\
\hline 32 & $\begin{array}{l}\text { Saya menyelesaikan masalah dengan } \\
\text { menggunakan informasi yang saya dapat dari } \\
\text { penyelidikan yang saya lakukan. }\end{array}$ & 1 & 2 & 3 & 4 & 5 & 1 & 2 & 3 & 4 & 5 \\
\hline 33 & $\begin{array}{l}\text { Berhasil dalam menyelesaikan tugas adalah } \\
\text { penting bagi saya }\end{array}$ & 1 & 2 & 3 & 4 & 5 & 1 & 2 & 3 & 4 & 5 \\
\hline 34 & $\begin{array}{l}\text { Saya bekerja sesuai dengan tugas yang diberikan } \\
\text { kepada saya }\end{array}$ & 1 & 2 & 3 & 4 & 5 & 1 & 2 & 3 & 4 & 5 \\
\hline 35 & $\begin{array}{l}\text { Saya tahu tujuan dari setiap topik pelajaran di } \\
\text { kelas ini. }\end{array}$ & 1 & 2 & 3 & 4 & 5 & 1 & 2 & 3 & 4 & 5 \\
\hline 36 & $\begin{array}{l}\text { Saya siap untuk mengikuti pelajaran tepat pada } \\
\text { waktunya. }\end{array}$ & 1 & 2 & 3 & 4 & 5 & 1 & 2 & 3 & 4 & 5 \\
\hline 37 & $\begin{array}{l}\text { Saya tahu apa yang harus saya capai dalam setiap } \\
\text { pelajaran. }\end{array}$ & 1 & 2 & 3 & 4 & 5 & 1 & 2 & 3 & 4 & 5 \\
\hline 38 & Saya mengikuti pelajaran dengan penuh perhatian & 1 & 2 & 3 & 4 & 5 & 1 & 2 & 3 & 4 & 5 \\
\hline 39 & $\begin{array}{l}\text { Saya berusaha untuk mengerti tugas saya di kelas } \\
\text { ini. }\end{array}$ & 1 & 2 & 3 & 4 & 5 & 1 & 2 & 3 & 4 & 5 \\
\hline 40 & $\begin{array}{l}\text { Saya tahu seberapa banyak tugas yang harus saya } \\
\text { lakukan. }\end{array}$ & 1 & 2 & 3 & 4 & 5 & 1 & 2 & 3 & 4 & 5 \\
\hline 41 & $\begin{array}{l}\text { Saya bekerjasama dengan siswa lain ketika } \\
\text { mengerjakan tugas. }\end{array}$ & 1 & 2 & 3 & 4 & 5 & 1 & 2 & 3 & 4 & 5 \\
\hline 42 & $\begin{array}{l}\text { Saya memakai bersama-sama buku dan fasilitas } \\
\text { lain dengan siswa-siswa lainnya ketika } \\
\text { mengerjakan tugas. }\end{array}$ & 1 & 2 & 3 & 4 & 5 & 1 & 2 & 3 & 4 & 5 \\
\hline 43 & $\begin{array}{l}\text { Ketika bekerja didalam grup, saya menemui } \\
\text { kerjasama tim yang baik. }\end{array}$ & 1 & 2 & 3 & 4 & 5 & 1 & 2 & 3 & 4 & 5 \\
\hline 44 & $\begin{array}{l}\text { Saya bekerja dengan siswa lain untuk tugas } \\
\text { kelompok di kelas. }\end{array}$ & 1 & 2 & 3 & 4 & 5 & 1 & 2 & 3 & 4 & 5 \\
\hline 45 & Saya belajar dari siswa lainnya di kelas ini. & 1 & 2 & 3 & 4 & 5 & 1 & 2 & 3 & 4 & 5 \\
\hline
\end{tabular}




\begin{tabular}{|l|l|l|l|l|l|l|l|l|l|l|l|l|}
\hline No & \multicolumn{1}{|c|}{ Pernyataan } & \multicolumn{3}{|c|}{ Sebenarnya } & \multicolumn{3}{|c|}{ Ideal/Dinginkan } \\
\hline 46 & Saya bekerja dengan siswa lainnya di kelas ini. & 1 & 2 & 3 & 4 & 5 & 1 & 2 & 3 & 4 & 5 \\
\hline 47 & $\begin{array}{l}\text { Saya bekerjasama dengan siswa lain dalam } \\
\text { kegiatan kelas. }\end{array}$ & 1 & 2 & 3 & 4 & 5 & 1 & 2 & 3 & 4 & 5 \\
\hline 48 & $\begin{array}{l}\text { Saya bekerja dengan siswa lain untuk mencapai } \\
\text { tujuan dari kelas ini. }\end{array}$ & 1 & 2 & 3 & 4 & 5 & 1 & 2 & 3 & 4 & 5 \\
\hline & $\begin{array}{l}\text { Bapak/ibu guru memberi perhatian yang sama } \\
\text { terhadap pertanyaan saya seperti kepada } \\
\text { pertanyaan siswa lainnya. }\end{array}$ & 1 & 2 & 3 & 4 & 5 & 1 & 2 & 3 & 4 & 5 \\
\hline 50 & $\begin{array}{l}\text { Saya mendapat bantuan bapak/ibu guru sama } \\
\text { seperti siswa lainnya. }\end{array}$ & 1 & 2 & 3 & 4 & 5 & 1 & 2 & 3 & 4 & 5 \\
\hline 51 & $\begin{array}{l}\text { Saya mendapat kesempatan bicara yang sama } \\
\text { seperti siswa lainnya }\end{array}$ & 1 & 2 & 3 & 4 & 5 & 1 & 2 & 3 & 4 & 5 \\
\hline 52 & $\begin{array}{l}\text { Saya mendapat perlakuan yang sama seperti siswa } \\
\text { lainnya. }\end{array}$ & 1 & 2 & 3 & 4 & 5 & 1 & 2 & 3 & 4 & 5 \\
\hline 53 & $\begin{array}{l}\text { Saya mendapat dorongan yang sama seperti siswa } \\
\text { lainnya. }\end{array}$ & 1 & 2 & 3 & 4 & 5 & 1 & 2 & 3 & 4 & 5 \\
\hline 54 & $\begin{array}{l}\text { Saya mendapat kesempatan untuk berpartisipasi } \\
\text { dalam diskusi kelas seperti siswa lainnya. }\end{array}$ & 1 & 2 & 3 & 4 & 5 & 1 & 2 & 3 & 4 & 5 \\
\hline 55 & $\begin{array}{l}\text { Pekerjaan saya mendapat penghargaan seperti } \\
\text { siswa lainnya. }\end{array}$ & 1 & 2 & 3 & 4 & 5 & 1 & 2 & 3 & 4 & 5 \\
\hline 56 & $\begin{array}{l}\text { Saya mendapat kesempatan yang sama untuk } \\
\text { menjawab pertanyaan seperti siswa lainnya. }\end{array}$ & 1 & 2 & 3 & 4 & 5 & 1 & 2 & 3 & 4 & 5 \\
\hline
\end{tabular}

